UDC 811.113.6

Natalia Aseeva

St. Petersburg State University

\title{
THE USAGE OF MULTIETHNIC YOUTH LANGUAGE IN DOUGLAS FOLEY'S WRITING
}

For citation: Aseeva N. The usage of multiethnic youth language in Douglas Foley's writing. Scandinavian Philology, 2020, vol. 18, issue 1, pp. 21-31. https://doi.org/10.21638/11701/spbu21.2020.102

The following article deals with usage of lexical features of multiethnic youth language in Douglas Foley's novels, namely, Shoo bre, Shoo len, and Shoo mannen. Having lived in one of Stockholm's most ethnically and culturally diverse areas, Alby, Foley had first-hand experience of communicating with young first and second-generation immigrants who spoke a variety of different mother tongues and had only one language that united them all - Swedish. The variation used by these young people differed from standard vernacular in terms of phonology, grammar, syntax, and, most noticeably, vocabulary. Along with classical features of Swedish vernacular they used slang words and swearwords from other languages, had various deviations from traditional grammar and syntax rules, and they added different discourse particles, emphatic elements, and code-switching to their speech. This new variation of Swedish was becoming more and more widespread in the suburbs of big cities, which understandably sparked a large interest among Swedish linguists. Today, this variation is known as "multiethnic youth language". The aim of this article is to analyse the lexical features of multiethnic youth language used by Douglas Foley and to determine the authenticity of this usage and what effect it has on the text. The data from the "Language and language use among young people in multilingual urban settings" project, conducted by Swedish linguists, is used as a basis for analysis.

Keywords: Swedish, multiethnic youth language, slang, linguistic variation.

Douglas Foley is a British-Swedish writer born in Cardiff, Wales in 1949. Since his father served in the British Armed Forces and often had to relocate, young Douglas and his family lived in various countries 
during his childhood years including North Africa and Hong Kong. He moved to Sweden in the late 1960s to work as a cook in the restaurant "Operakällaren" in Stockholm. Foley later studied anthropology and literary history at university. For a number of years, he worked as a librarian in one of the schools in Alby, which is a suburb in Botkyrka Municipality within Stockholm. Historically and up to this day, Alby has been known for having a very high percentage of residents with a foreign background ( $83.5 \%$ as of 2016). This has provided Foley with an opportunity to work with a great number of students from all over the world who had different native languages and only one common language to communicate in - Swedish.

Just like in any other Stockholm suburb with a high percentage of young first and second-generation immigrants, the result of this was a variation of Swedish that differed from the local dialect. This variation is commonly known as a "Rinkeby Swedish" (after one of Stockholm's suburbs) "immigrant Swedish" or even "suburb Swedish", but is officially called "multiethnic youth language" in Swedish linguistics.

Sweden has for many years been an incredibly culturally diverse country since it has experienced several waves of immigrants and refugees. Since the end of the Second World War, this country has become home for people from Europe, Africa, Middle East, etc. The new inhabitants mainly settled in constantly growing suburbs of such Swedish cities as Stockholm, Gothenburg, and Malmo, which has resulted in the fact that many of these districts still have a predominant number of people with a foreign background. Children and teenagers who were growing up in such areas could speak different mother tongues, had various levels of Swedish, and were constantly surrounded by different variations of this language, be it dialects, sociolects, registers, or stages of interlanguage.

This is why upon moving to Alby, the writer found himself feeling more comfortable and accepted - almost everyone around him were also immigrants and it was easier to build relationships with people. It was a very diverse and giving environment and he felt inspired to write about the experiences of young people living in such areas. Douglas Foley is the author of Ingen ätervändo (No return, 2001); a series of books about a character called Habib, such as Habib: meningen med livet (Habib: the meaning of life, 2005) or Habib: änglar här och där (Habib: angels here and there, 2008), and others. However, this article focuses on 
the language of three of his novels: Shoo bre (2003), Shoo len (2009) and Shoo mannen (2012) which can be translated as "Hey bro", "Hey, what's up", and "Hey man".

Shoo bre is a book about two friends, Elias and Oscar, and their last year of high school. They come from the same district with a high population of immigrants, but make very different life choices. Oscar tries to be a good student and does his best, while Elias does not care about school at all and is engaged in criminal activities. They end up falling in love with two women, but these love stories are quite far from the ordinary.

Shoo len tells a story of two "gangs" of young people: Karim, Gabi, Sebbe, Metin, Jamal, and Hani (a guy group) and Josefine, Ella, Hanan, and Nikoo (a group of girls). We follow their lives during the last year of high school and learn about their relationships and the overall situation in the school which does not really pay much attention to either students or their safety, resulting in a catastrophe.

Shoo mannen tells the story of a young man called Djano who dreams about becoming a chef and opening his own restaurant and his old friend Rafa who tries to convince Djano that they should rob a place in order to get easy money. Djano is torn between helping his friend and staying out of trouble.

Similar topics, characters, and styles make it possible to analyse these three books within the same article, especially since they rely heavily on using multiethnic youth language in most of the dialogs between young people. Shoo len has been previously analysed by Pia Hemzelius [Hemzelius, 2010] and Shoo bre - by Josefin Bardby [Bardby, 2014]. In contrast to their works, the following article studies both of these novels simultaneously along with the novel Shoo mannen and combines both qualitative and quantitative research. It also focuses solely on lexical features and uses a different classification of its elements.

The aim of this article is to find out how authentic the usage of multiethnic youth language is, how it correlates with the elements of standard Swedish vernacular, and how it impacts the texts' style. In order to do so we have to first outline the specific features of multiethnic youth language based on previous research.

The main data for comparison is provided by the "Language and language use among young people in multilingual urban settings" project conducted by twenty Swedish linguists between 2001 and 2006 . 
The main goal of this project was to describe new variations of Swedish spoken in multicultural areas of such cities as Stockholm, Gothenburg, and Malmo. It focused primarily on phonology, vocabulary, syntax, and grammar of young people who used these variations in their speech, as well as on other sociolinguistic aspects.

Before going into the analysis of Douglas Foley's texts it is worth describing the main features of the multiethnic youth language.

1) One of its key phonetic features is a "choppy" prosody and a different pronunciation of loanwords ( $[t /]$ instead of a fricative $[/]$ and $[z]$ instead of $[s]$, because those sounds are often present in speakers' mother tongues) [Boyd, 2010, p. 25].

2) The overall grammar of multiethnic youth language is not that different, but still it includes various deviations from traditional grammar rules in such aspects as conjugation of regular and irregular verbs, usage of neuter and common gender (that includes both feminine and masculine genders), definite and indefinite forms of nouns and adjectives, prepositions, plural forms, pronouns, and especially possessive ones, etc.

3) A subject-verb order variation that can deviate from the ground rule (some speakers do not apply the inversion where necessary and use the XSV word order instead). According to the rules of traditional Swedish grammar, the finite verb in a main clause is placed on the second position, so whenever a main clause begins with something other than the subject, an inversion occurs (which results in a XVS word order). This feature has always been difficult to acquire for people who have Swedish as their second language and is strongly associated with language variations used by first and second-generation immigrants. However, the project concluded that incorrect word order was used in only $3.5 \%$ of cases [Ganuza, 2008, p. 64].

4) Code-switching, since many speakers use various languages at home, with their friends, teachers, etc.

5) Various partially modified conventionalised word combinations and novel word combinations, which results in deviations in phraseology.

6) Rich and varied slang, which includes loanwords from a variety of languages from all over the world, such as Greek, Turk- 
ish, Arabic, Spanish, etc., which makes it different from the standard Swedish slang that takes loanwords from dialects, widely spoken languages and the so called "secret languages" like knoparmojet (chimney sweeper's language), Romani, argot languages and månsing (Swedish merchants' language) [Möijer, 1989, p. 61]. In some cases, it might be difficult or even impossible to determine from which language a word was loaned from because young people who use multiethnic youth slang are surrounded by a large number of languages in their everyday life [Kotsinas, 2004, p. 10].

7) Some features of the standard spoken Swedish: traditional slang words, prefixes and suffixes, swearwords, discourse particles, excessive use of emphatic words, ellipses, corrections, repetitions, pauses, etc.

It can be also worth outlining the sociolinguistic aspects of multiethnic youth language, in other words, how we define it and why young people use it in their speech. It is impossible to call it a dialect because it is not used by a vast majority of people living in a specific area. We cannot quite group it in with sociolects either because young people use it as a register, which means that it is only a temporary switch between variations caused by the situation, their motives, goals, and recipients [Bijvoet, Fraurud, 2013, p.372]. They often switch to this register for very specific reasons, which include hiding information from individuals, when the speaker does not want to reveal it to "outsiders", expressing linguistic creativity and using new words and expressions, showing how cool and different they are compared to the "ordinary" people, expressing pride in their background and cultural heritage, showing solidarity and respect to their parents or peers who do not have a high level of Swedish, expressing irony or sarcasm in relation to stereotypes towards linguistic features of Swedish spoken by immigrants, and showing protest against society that does not identify the speaker as a Swede because of their ethnicity, appearance, or background, even if the speaker was born and raised in Sweden [Kotsinas, 2005, p. 9].

Now that we have determined the key features of multiethnic youth language it is possible to discuss their features in Foley's texts and determine their authenticity. For the purpose of this article, the following 
analysis focuses solely on the lexical features of the multiethnic youth language used in the texts because they make up an absolute majority of all multiethnic elements used by the author. They also have a larger stylistic effect and are strongly associated with the speech of young people in multicultural areas. These lexical features include both standard and multiethnic slang words, swearwords, emphatic elements, code-switching, and discourse particles. The material used for analysis includes dialogs that are written using said variation. A continuous sampling method is used to obtain examples from all novels and the number of uses of each element in the texts is provided in brackets.

The most prominent feature of multiethnic youth language that can be found in Foley's texts is slang, which is not surprising considering the fact that it is the most noticeable, recognisable, and widespread feature used by young people in multicultural areas. Just like in real life, slang words used by the characters are mainly connected to naming people of different genders, criminal activities and money, and are often loaned from such languages as Turkish, Arabic, Farsi, Spanish, etc.

1) Haffa ("to get, to find", 10 cases): Tiotusen för att haffa värsta lastbilen och köra den till stan [Foley, 2012, p. 48]: "Ten grand for finding a sick truck and driving it to town"; Och blir vi haffade får han ta skulden [Foley, 2012, p. 71]: "If they get us, he'll have to take the blame".

2) Tjaba ("hey, hi", 2 cases) "Tjaba", sa Josefin med en röst som inte var direkt avvisande [Foley, 2009, p. 49]: "Hey, said Josefin in a voice that wasn't too indifferent".

3) Svär ("swear", 87 cases) Jag svär, en dag ska han få stryk [Foley, 2009, p. 13]: "He's gonna get his ass kicked one day, I swear"; Jag svär, mannen, efter tre fyra år äger vi vår första restaurang [Foley, 2012, p. 28]: "I swear man, three or four years later we'll have our first restaurant".

4) Mecka ("roll (a joint)", 5 cases) Klarar inte ens av att mecka en joint [Foley, 2009, p. 188]: "He can't even roll a joint"; Okej, fast man borde mecka en joint, egentligen [Foley, 2012, p. 276]: "Okay, he should really roll a joint though".

5) Händish ("to go on", 4 cases) Han säger shoo bre och jag svarar shoo bre vad händish [Foley, 2012, p. 83]: "He says hey man and I say hey man what's up". 
6) Jiddra ("to argue", 7 cases): Jiddra inte om skolan [Foley, 2009, p.20]: "Don't argue about school"; Vafan jiddrar du om? [Foley, 2012, p. 140]: “The hell you going on about?".

7) Habibi ("loved one, honey”, 4 cases): Fan är du kåt på lilla habibi fröken? [Foley, 2012, p.67]: "Shit, are you horny for that sweet teacher?".

Besides a more "neutral" slang, swearwords are also quite prominent in the characters' speech, as well as in their real life group of protagonists. These swearwords can be divided into two groups: the ones that are historically connected to taboo topics in Sweden, like religion, and are therefore a part of standard Swedish slang (see examples № 8 and 9); and the ones that are loaned from other languages and might be connected to a different kind of taboos, like genitalia and sex (see example №4).

8) Fan ("damn, hell, devil", 82 cases): De ska visa... fan heter du nu igen [Foley, 2009, p. 163]: “They'll show... what's your damn name again”; Fan, jag svär, jag är vrålhungrig [Foley, 2012, p. 183]: "I am hella hungry, I swear".

9) Jävla (“damn, fucking”, 25 cases): Jag svär, jag är så jävla nervös [Foley, 2009, p. 253]: "I swear, I'm so damn nervous"; Vad är det du gör som är så jävla viktig att du är så upptagen hela tiden? [Foley, 2012, p. 188]: "What is it that you do that is so damn important that you're so busy all the time?"; Jag svär, du är så jävla äcklig [Foley, 2012, p. 180]: "I swear, you're so fucking gross".

10) Bög ("faggot", 14 cases): Har ni inte fattat len, Oscar är värsta bög jao [Foley, 2012, p. 66]: "Don't you understand that Oscar is a fucking faggot, yo".

11) Bazza/bazz ("to fuck", 10 cases): Hon kanske ville bazza dej [Foley, 2009, p. 219]: "She probably wanted to fuck you"; Hon fär säkert mer bazz än du [Foley, 2012, p. 188]: "She definitely gets fucked more often than you".

The next big group of lexical features used by Foley's characters consists of various emphatic words and particles that are commonly used by many multiethnic youth language speakers as well as by people who use the standard Swedish vernacular. These kinds of words usually express a meaning similar to "very, really, extremely", so the translations of the words given below are word-for-word, while the examples from books are translated in a literary manner. The lexical elements listed be- 
low have already become a part of standard Swedish slang and partially lost their original meaning.

12) Fett ("fat", 17 cases): Det är något jag ångrar, typ fett, men eftersom du lovade att inte bli sur eller arg så... [Foley, 2009, p. 152]: "It's something I regret, like, a ton, but since you promised not to get upset or mad so..."; Du hade fett mycket tid när vi var $i$ bastun? [Foley, 2012, p. 188]: "You had a shit ton of time when we were in a sauna?".

13) Värsta ("the worst", 70 cases): Det kan bli värsta brand ju [Foley, 2009, p.262]: It can turn into a real fire; Fan vad du har blivit värsta pluggis bre [Foley, 2012, p. 52]: "Fuck, you've become a hell of a nerd bro".

14) Grymt ("grim", 4 cases): "Han var grymt bra jao", stönade Kawtar [Foley, 2012, p. 42]: "He was really good you know, moaned Kawtar".

Since first and second-generation immigrants tend to speak more than one language in their everyday life, code-switching is something that can often characterise their speech. The examples given below present code-switching as using consecutive phrases or expressions rather than singular words, which can be classified as loanwords. Most cases of code-switching to native languages from Shoo len include Farsi, from Shoo bre - Spanish.

15) Koja miri, in mogeje shab (Farsi, "where are you going, it's late in the evening", 1 case): Koja miri, in mogeje shab? [Foley, 2009, p.93]: "Koja miri, in mogeje shab?".

16) Be man dorogh nago (Farsi, "Don't lie to me", 1 case): Be man dorogh nago! [Foley, 2009, p. 149]: "Be man dorogh nago!".

17) Ayúdame por favor (Spanish, "please help me", 1 case): Snälla Oscar, ayúdame por favor [Foley, 2012, p. 228]: "Dear Oscar, ayúdame por favor".

18) Sabes qué (Spanish, "you know what" 1 case): Sabes qué? Din pappa och jag har varit jätteoroliga [Foley, 2012, p. 128]: "Sabes qué? Your father and I were really worried".

Discourse particles from both standard Swedish vernacular (see examples № 19 and 20) and multiethnic youth language (see example № 21) are very common in young people's speech. They can function as signals for 
citation or uncertainty, draw the recipient's attention to something the speaker finds important, reveal a desire to specify or correct something that has already been said, etc. [Kotsinas, 2004, p.42]. Therefore, their meaning in direct speech can be quite different from the original one and, contrary to popular belief, they cannot be considered "junk words", because they have a specific semantic role in peoples' utterances.

19) Typ ("like", 113 cases): Han vill typ undvika dom han umgicks med förut [Foley, 2012, p. 291]: "He wants to, like, avoid the people he was talking to before"; Det hander att jag överdriver, ibland typ [Foley, 2009, p. 218]: "I can exaggerate, like, sometimes".

20) $\mathrm{Ba}$ ("like" as a citation marker, 3 cases): Jag ba... Jag sa att hela idén med artikeln var min från första början [Foley, 2012, p.341]: "I was like... I said that the whole idea for the article was originally mine".

21) Jao ("yo, you, you know, hey" or similar, 15 cases): Synd. Hon är chok snygg jao [Foley, 2012, p. 159]: “That's a shame. She's real pretty you know".

The result of the analysis carried out above demonstrates that Douglas Foley consequently uses the most prominent and wide-spread lexical features of Swedish multiethnic youth language which include (but are not limited by) both standard and multiethnic slang words, swearwords, emphatic elements, code-switching, and discourse particles.

Just like in real life, multiple slang words used by the characters mainly refer to people, criminal activities or money, and can be loaned from both "classical" sources, like the chimney sweeper's language or Romani, and various world languages, like Turkish, Arabic, or Spanish. The swearwords are derived from both traditional and non-traditional taboo topics like religion or sex. Interestingly enough, the majority of emphatic elements and discourse particles are derived from the standard Swedish vernacular. Code-switching to mother tongues, which is very common among first and second-generation immigrants, can, however, be characterised as something typical specifically for the multiethnic youth language.

It is therefore possible to conclude that Douglas Foley uses a very authentic variation of multiethnic youth language in all of his novels, which allows him to make his characters more realistic and "alive". It creates a style that closely resembles the one that is used among young 
people with a foreign background, which provides readers with a deeper understanding of characters' motives, feelings, and way of thinking.

\section{REFERENCES}

Bardby J. Shoo bre, kif halik? En kvantitativ korpusundersökning av multietniskt ungdomsspråk i Douglas Foleys Shoo bre. Lund: Språk-och litteraturcentrum, 2014. 35 p. (In Swedish)

Bijvoet E., Fraurud K. "Rinkebysvenska" och andra konstruktioner av språklig variation i dagens flerspråkiga Sverige. Svenska som andraspråk: i forskning, undervisning och samhälle. Lund: Studentlitteratur, 2013. P.369-396. (In Swedish)

Boyd S. Vems svenska ska beskrivas? Problem med att använda termen native speaker om ungdomar i flerspråkiga storstadsmiljöer och termen varietet om deras språkbruk. Svenskans beskrivning. 2008, vol. 30, Stockholm: Institutionen för nordiska språk, Stockholms universitet, 2010. P. 13-36. (In Swedish)

Doggelito D., Kotsinas U.-B. Förortsslang. Stockholm: Norstedts ordbok, 2004. 215 p. (In Swedish)

Foley D. Shoo bre. Stockholm: Bonnier Carlsen, 2012. 346 p. (In Swedish)

Foley D. Shoo len. Stockholm: Bonnier Carlsen, 2009. 276 p. (In Swedish)

Foley D. Shoo mannen. Stockholm: Bonnier Carlsen, 2012. 379 p. (In Swedish)

Ganuza N. Ordföljdsvariation som språklig strategi bland ungdomar i flerspråkiga storstadsmiljöer. Nordand: nordisk tidsskrift for andrespråksforskning. № 2, 2008. Bergen: Fagbokforlaget, 2008. P. 57-81. (In Swedish)

Hemzelius P. Ey, "foleyska" len - en undersökning av det litterära talspråket $i$ Shoo len av Douglas Foley. Lund: Språk-och litteraturcentrum, 2010. 38 p. (In Swedish)

Kotsinas U.-B. Invandrarsvenska. Uppsala: Hallgren \& Fallgren, 2005. 264 p. (In Swedish)

Kotsinas U.-B. Ungdomsspråk. Uppsala: Hallgren \& Fallgren, 2004. 184 p. (In Swedish)

Möijer K. Svensk språkstil: stil \& stilanalys. Solna: Ekelund, 1989. 143 p. (In Swedish)

Наталья Асеева

Санкт-Петербургский государственный университет

\section{ИСПОЛЬЗОВАНИЕ МУЛЬТИЭТНИЧЕСКОГО ЯЗЫКА МОЛОДЕЖИ В ТЕКСТАХ ДУГЛАСА ФОУЛИ}

Для цитирования: Aseeva $N$. The usage of multiethnic youth language in Douglas Foley's writing // Скандинавская филология. 2020. Т. 18. Вып. 1. С. 21-31. https://doi.org/10.21638/11701/spbu21.2020.102

Предметом данной статьи является использование лексических особенностей мультиэтнического языка молодежи в романах британско-шведского писателя Дугласа Фоули «Shoo bre», «Shoo len» и «Shoo mannen». Вскоре после 
переезда в Швецию Фоули поселился в одном из самых этнически и культурно разнообразных районов Стокгольма, Альбю, где в течение нескольких лет занимал должность школьного библиотекаря и работал с молодыми иммигрантами в первом или втором поколении, которые говорили на самых разных языках мира. Единственным общим для них языком являлся шведский, однако используемый ими языковой вариант обладал характерными фонетическими, грамматическими, синтаксическими и лексическими особенностями, которые отличали его от нормы языка. Наряду с традиционными элементами разговорной речи эти подростки употребляли сленг, прагматические частицы, эмфатические конструкции и ругательства из других языков, периодически нарушали правила грамматики или синтаксиса, а также использовали переключение кодов. Данный вариант шведского языка получал все большее распространение на окраинах крупных городов, что не могло не вызвать интерес шведских лингвистов в современной науке он носит название «мультиэтнического языка молодежи». Данная статья посвящена анализу лексических особенностей мультиэтнического варианта шведского языка в произведениях Дугласа Фоули с целью определения аутентичности их употребления и степени влияния на текст. В качестве основы для сравнения использованы данные проекта «Språk och språkbruk bland ungdomar i flerspråkiga storstadsmiljöer» («Язык и его употребление среди молодежи в многоязычных районах крупных городов»), осуществленного шведскими лингвистами.

Ключевые слова: шведский, мультиэтнический язык молодежи, сленг, лингвистическая вариативность.

\author{
Natalia Aseeva \\ PhD Student, \\ St. Petersburg State University, \\ 7-9, Universitetskaya nab., St. Petersburg, 199034, Russia \\ E-mail: st046955@student.spbu.ru
}

\title{
Асеева Наталья Андреевна
}

аспирант,

Санкт-Петербургский государственный университет,

Россия, 199034, Санкт-Петербург, Университетская наб., 7-9

E-mail: st046955@student.spbu.ru

Received: March 30, 2020

Accepted: May 25, 2020 